\title{
From the mountain to the castle: Natural spaces and golden objects in Kallimachos and Chrysorrhoe
}

Rui Carlos Fonseca

(University of Lisbon)

\begin{abstract}
In this paper, I analyze the journey of three brothers told in the late Byzantine romance Kallimachos and Chrysorrhoe as well as the way in which, along their journey, natural elements and golden objects function as thresholds between human society and the supernatural world.
\end{abstract}

\section{Keywords}

Byzantine romance; landscape; golden objects; supernatural; thresholds; rite of passage

A preliminary version of this paper was presented at Leeds International Medieval Congress 2019. This article was written as part of my postdoctoral research on Byzantine romance, funded by the FCT - Fundação para a Ciência e a Tecnologia (SFRH/BPD/99542/2014). I wish to express my deepest gratitude to GraecoLatina Brunensia's editors and the anonymous reviewers for their insightful suggestions. 


\section{Introduction}

The production of Byzantine romance experienced a second revival during the Palaiologan period, after Constantinople's recovery from the Nicaean siege in 1261 and continued up to the late fifteenth century. These re-established tales of love and adventure engage both with the Komnenian and Hellenistic literary traditions of the Greek novel. Nonetheless, despite similarities in content and plot motifs, there are important differences in terms of its models. The fictional world of Komnenian and Hellenistic novels, based on the cultural and religious values of ancient Greek society, gives way to a new literary framework characterized by the prevalence of the marvelous and the supernatural. The characters are no longer seen traveling around the Mediterranean, but rather entering faraway lands beyond human civilization with very few, or no, specific geographical locations, as in the world of fairy tales. The literary setting of these tales mimics the Greek topography no more. Instead in late Byzantine romances, heroes are native princes of foreign countries who depart for unknown faraway lands. ${ }^{1}$ Lacking the traditional Hellenic-Barbarian dichotomy, Palaiologan romances impress with their exotic elements, such as marvelous castles, dangerous landscapes, magical creatures, and tokens empowered with outstanding qualities. Imbued with heterogeneous traits, drawn from both western and eastern narratives, and features of different literary genres, from ancient epic to medieval chivalric, Palaiologan romances were intended to entertain elite audiences with splendid descriptions of Eros' realm and journeys to magical lands. ${ }^{2}$

Livistros and Rhodamne (mid-13 ${ }^{\text {th }}$ century), Velthandros and Chrysantza (late $13^{\text {th }}$ century), and Kallimachos and Chrysorrhoe (first half of $14^{\text {th }}$ century) belong to the late Byzantine romances. Composed in political verse, the fifteen-syllable meter, all three are anonymous except perhaps Kallimachos, whose author most scholars believe to be Andronikos Komnenos Palaiologos, a member of the ruling imperial family at the time. ${ }^{3}$ Notwithstanding the issues concerning their chronology, these three romances were undoubtedly produced relatively close to each other in time, share common patterns and plot motifs, their contents being arranged in a bipartite narrative structure. The starting point is usually a journey that involves a displacement from home, a "removal from the familiar native environment": 4 a young prince leaves his homeland on a quest that takes

1 On the evolution of the Byzantine romance and the changes made by Palaiologan writers differentiating them from their predecessors, see e.g. Arrignon \& Duneau (1992: pp. 283-290); Cupane (1994: pp. 103-126; esp. 115-123 on the foreign fictional world depicted within late Byzantine romances).

2 On the reception of later Byzantine romances by a listening elite audience, see Cupane (2016b: pp. 479-494). See also Conca (1986: p. 45).

3 Kallimachos' authorship is based on hypothetical evidence: in an epigram that has come down to us, Manuel Philes summarizes a love story written by Andronikos; his synoptic presentation and allegorical interpretation of it disclose important resemblances with Kallimachos' plot. This hypothesis was originally raised by Martini (1896: pp. 460-471). On Philes' epigram and discussions regarding Kallimachos' authorship, see Pichard (1956: pp. xv-xxxi); Knös (1962: pp. 274-295); Hunger (1968: pp. 421-422); Agapitos (1991: p. 16, n. 16); Beaton (1996a: pp. 104, 190-192); Beaton (1996b: pp. 723-724); Henrich (2012: pp. 77-84); Lampaki (2014: pp. 47-63); Cupane (2014: pp. 196-197); Cupane (2016a: pp. 95-98, 114-118).

4 Cupane (2014: p. 184). See also Cupane (1994: p. 103). 
him to a castle, where he meets a beautiful princess. After hero and heroine overcome certain perils and endure the bittersweet pains of love, the story resets and a new set of adventures takes place. The hero is again on the move, departing from one castle to reach another. In fact, the castle is one of the most important, even innovative, elements of these late medieval Byzantine romances. ${ }^{5}$ Castles are the main narrative spatial points upon which the entire fictional action is based, since everything happens within and between them; each story develops from one castle, usually located in human society, and runs along the path the characters follow to reach another castle, commonly set in the supernatural-oneiric realm. Thus the journey between one castle and another (and back) is the essence of the plot of Palaiologan romance.

The marvelous castle, depicted with magnificent and charming gardens, stands as a liminal place, separated from the real world by natural obstacles that are difficult to overcome, such as mountains, rivers, and deserts. ${ }^{6}$ Kallimachos' Drakontokastron, Dragon's Castle, is a perfect example of this. As Agapitos puts it, "From a spatial point of view the Drakontokastron stands in the center of the romance's geography." In the first half of the narrative, Dragon's Castle is the hero's point of arrival, the location of his heroic and erotic achievements, his home but also his locus mortis. On the other hand, in the second half, Dragon's Castle is the place of the hero's revival by magic, then his point of departure as well as his place of return at the story's end. ${ }^{8}$ Located in a magical, fairy-tale world beyond human society, between the castle of Kallimachos' father and the palace of Kallimachos' rival, the only way to Dragon's Castle is through a wild and dangerous landscape marked by natural and supernatural borders, which are overcome. In this paper, I will focus on Kallimachos and Chrysorrhoe, examining elements of the natural world, and the golden objects the hero comes across on his travels. These elements become gateways, marking transitional spaces simultaneously separating and granting passage, thus serving as thresholds between different worlds.

\section{The mountain, the meadow, and the region of cliffs}

Kallimachos and Chrysorrhoe features three brothers, the sons of a foreign king (25 Báp $\beta \alpha$  departure from home is motivated by the problem of determining the royal succession: they leave at their father's order, with a great army and in search of adventure; they have

5 The importance of the castle in Byzantine romances has been discussed by Cupane (1978: pp. 229-267).

6 Cupane (2015: p. 99).

7 Agapitos (1991: p. 287).

8 On the bipartite narrative structure of Kallimachos, see e.g. Beaton (1996a: pp. 118-121); Agapitos (2004: pp. 28-29). See also Fonseca (2017: pp. 135-149) on the tripartite structure of the first half of this romance. Specifically on Kallimachos' narrative space, see Agapitos (1991: pp. 282-297).

9 For the Greek text of Kallimachos and Chrysorrhoe (henceforth $K C$ ), I follow Cupane's edition (Cupane 1995: pp. 45-213). English quotes are taken from Betts' translation (Betts 1995: pp. 37-87). 
no predefined plan or route but they are expected to accomplish outstanding heroic deeds:

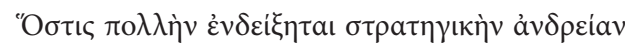

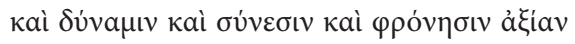

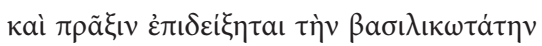

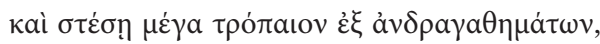

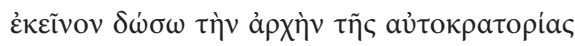

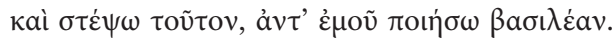
(KC 62-67)

"The one who shows great military valor, strength, intelligence and proper wisdom, the one who acts in the most kingly way, and gains a great trophy with his mighty exploits, to him shall I give the command of the empire, him shall I crown and make king in my place."

This opening bears some important considerations about the emerging plot. The quest the three brothers undertake by kingly command is not so much a quest for adventure, but rather a rite of passage, in the sense discussed by Van Gennep. ${ }^{10}$ In order that a young prince to earn access to kingship, passing to a higher stage in the royal hierarchical order, he must fulfill certain tasks. His coronation does not lie on direct succession, but requires a process of transition, here in the form of a contest between brothers. The contest motif can also be seen in Velthandros, where a beauty contest is held between forty maidens, and in Livistros, where the hero and his rival face each other in a tournament. Both these contests represent the path to a transition in the status of the young heroes, from adventurer to lover in one case, from unmarried to married in the other. Whatever its nature, the passage from one social and/or symbolic status to another always brings changes, and these changes require the accomplishment of certain deeds. In Kallimachos, the quest of the three brothers is intended to be a transitional period - a preliminary yet necessary stage - before the victorious candidate can accede to the throne and the crown. ${ }^{11}$ The fact that the royal decree remains unfulfilled has no bearing on the significance of the quest's framework as a rite of passage, which must be accomplished far from the familiar environment.

The king's orders trigger the rite of separation (to employ Van Gennep's terminology) for his sons, since they depart from their homeland and abandon their status as neophytes and the age of boyhood. The journey itself, on the other hand, is a transition rite marked by natural borders, whose transgression is both physical and symbolic. It is a moment of in-between-ness, where the known safety of home is left behind and the unknown danger of foreign lands lies ahead. ${ }^{12}$ Kallimachos is the only brother who we actually see going through a transformational process: he starts as the youngest son in

10 Van Gennep's book Les rites de passage was originally published in French in 1909, and translated into English in 1960.

11 On the rites of enthronement, see Van Gennep (1960: pp. 110-113).

12 Turner (1991: p. 105) acknowledges that the pedagogics of liminality entails a separation from the generic bond of communitas. 
his father's kingdom, then becomes lord of Dragon's Castle and marries a beautiful maiden of royal birth. ${ }^{13}$ He attains the stage of kingship, not by inheriting it from his ancestors, but thanks to his fearlessness in facing the wild landscape. Dangerous nature represents an intermediate stage in Kallimachos' process of change; he passes from boyhood to manhood, from non-lover to lover, from prince to lord via the liminal period of his journey. The three natural obstacles he faces on the way to Dragon's Castle are a mountain, a meadow, and a region of cliffs. In what follows, I will examine these elements, showing the peril each represents as thresholds between the real world and the supernatural realm.

The first great difficulty of the journey comes in the form of an anabasis. After traveling across many remote and trackless lands, the three brothers, along with their large army, equipment, and treasures, find themselves standing in a deserted place before a mountain (ßouvóc). The mountain impresses right away by its great height, its summit reaching the heavens. It's a place of stony ground, covered by a dense forest, with no trace of human presence, or path by which to ascend $(K C 79-81)$. The three brothers react differently faced with the danger of the mountain, and in this their portrayal as a homogeneous group starts to fade. Viewed from the ground, a mountain appears as a vertical line stretching up, with no visible end, linking earth and heaven, symbolizing a junction between one realm and the other. ${ }^{14}$ The mountain, remarkable for the density of its trees and its boundless height, functions as a threshold between the visible and the invisible worlds. Kallimachos' brothers fear the unknown, what is hidden beyond the clouds, impossible to see from below. The firstborn suggests that they continue their

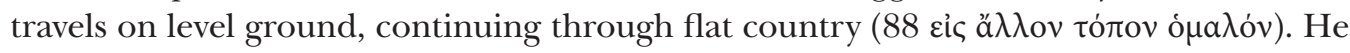
does not see the need to ascend or enter into another world, preferring the horizontal, known safety of the society of men to the vertical, unknown danger of the mountain. ${ }^{15}$ As Agapitos points out, the mountain plays an important role in the removal of the three brothers from human society, since it stands as an obstacle both technical (preventing the army from going forward) and psychological (since the characters are afraid). ${ }^{16}$ However, spurred by Kallimachos' rebuke and bolder character, the three undertake the ascent of the mountain. The climb is extremely hard; there is no path to follow, and, according to Kallimachos' later report before the trial at his rival's palace, the three brothers are forced to make detours through the dense forest and its darkness ( $K C$ 2522-2523). The mountain, untouched by human hand, thus resembles a natural maze where these travelers easily get lost, being forced to retrace their steps and try other routes until they manage to reach its top.

13 On the atypical and symbolic marriage of Kallimachos and Chrysorrhoe, due to the isolated position of Dragon's Castle, see Garland (1990: pp. 111-117).

14 Chevalier \& Gheerbrant (1990: pp. 645, 648-649).

15 Cupane (2017: p. 106) acknowledges that the Byzantines considered the wild natural world as mainly dangerous, and their fear is reflected in their fictional narratives. In this light, it can be argued that the fearfulness of the two older brothers before the wild mountain is a conventional Byzantine reaction. Kallimachos' fearless response thus becomes atypical, due to his heroic status.

16 Agapitos (1991: p. 283). 
This mountain seems to present the main features of the mythical image of the oros discussed by Buxton: mountains are "outside," "wild," "before," and "places of reversals."17 However, mountains could offer paths for travel and be exploited by light-armed troops, not by great armies, and could also serve as an initiatory space, a place for the military education of the adolescent male. ${ }^{18}$ Buxton's analysis is in line with Van Gennep's, ${ }^{19}$ since both consider the mountain a natural boundary, marking the end of human society and the entrance into another world; it is a liminal place, a proper intermediary and neutral zone for a test and passage from one stage to another. For the three brothers, this is the first challenge in their transitional process towards manhood and to achieve the rank of kingship. In Velthandros, the route through the mountain is literally a passage. Wandering over eastern lands, the hero and his three squires come to a defile. The word employed

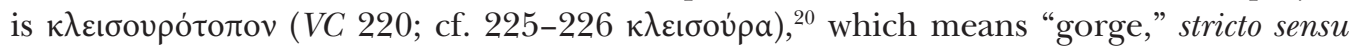
"a narrow pass between the mountains." Inside this pass, Velthandros slays a mighty group of countless bandits, thus reinforcing his status as warrior. He had already slain ten of his father's kinsmen in a meadow. The difference between the two slaughters lies in the fact that inside the pass Velthandros kills foreigners in a foreign land. Thus the mountainous setting here places his heroic actions in the other world, before he arrives at Erotokastron, Love's Castle. In Livistros, a mountainous landscape is the setting of a hunting scene followed by the hero's instruction in Love's mysteries. Accompanied by his kinsmen and friends, Livistros "went to mountain slopes (131 عic ópeıvòv ßouví$\tau \sigma \mathrm{v})$, to a wooded hill" and spent the entire day "on the plains, on the slopes and in the

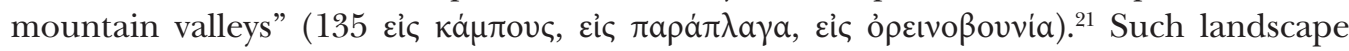
turns out to be not so much the place for sporting activities but rather the preliminary privileged space for the hero's education in the bittersweet lessons of passion. Livistros hears a kinsman explaining the marvel involving two turtledoves, and that same night he dreams he is taken by winged men to Eros' camp, where he swears allegiance to the God of Love. From a turtledove's hunter in the real mountainous world he becomes the prey in Eros's oneiric realm. The wild landscape here also plays an initiatory role.22

17 Buxton (1996: pp. 88-95).

18 Buxton (1996: pp. 83-84).

19 "The neutral zones are ordinary deserts, marshes, and most frequently virgin forests where everyone has full rights to travel and hunt. [...] Whoever passes from one to the other finds themselves physically and magico-religiously in a special situation for a certain length of time: the wavers between two worlds" (Van Gennep 1960: p. 18).

20 For the Greek text of Velthandros and Chrysantza (VC), I follow Cupane's edition (Cupane 1995: pp. 215305). English quotes are taken from Betts' translation (Betts 1995: pp. 5-30).

21 For the Greek text of Livistros and Rhodamne (LR), I follow Agapitos' edition (Agapitos 2006). English quotes are taken from Betts' translation (Betts 1995: pp. 95-185).

22 Priki (2019: pp. 69-100) has recently analyzed, in a comparative study, the dreams in Livistros as the privileged ritual spaces where initiation processes are undertaken, Eros acting as the executioner. The hero's first dream constitutes the main ritual for his initiation (p. 72), the rite of passage being triggered by the scene involving the turtledoves: Livistros causes the separation of the bird couple, and then he is the one separated from the real world by his dream experience (p. 75). Priki suggests that Livistros' dreams can be seen as visitations, insofar as Eros visits the dreamer's space in order to counsel or command him, and vanishes thereafter (p. 86). On Livistros' dreams as a time-honored narrative device and as a "marker of 
Let us return to Kallimachos. With much effort, the three brothers take around three months to reach the top of the mountain, where they find "a charming and pleasant spot, a wondrous meadow of quite exotic grace divided by a river of crystalline water"

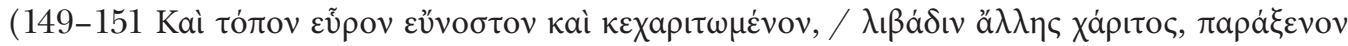

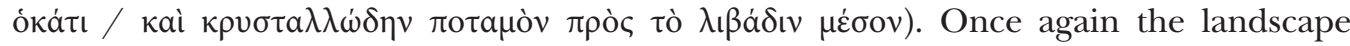
brings out the distinction between Kallimachos and his two older brothers, since he is the one who realizes that the meadow is not an appropriate place to perform deeds of courage. He insists that they leave this charming setting. This second rebuke at the second stop not only shows the contrast between the brothers (the accommodating and submissive attitude of the two oldest against the fearless and unhesitating attitude of the youngest), it also marks the contrast regarding the first space: the frightening sight of the mountain, which everyone but Kallimachos wants to avoid, is followed by the pleasant sight of the meadow, which the majority does not wish to leave. Despite the opposing reactions produced by the mountain and the meadow, both are dangerous and stand as natural thresholds. The meadow symbolizes the danger of detention, entailing a complete lack of gallant deeds. Velthandros' and Livistros' meadows are also places of contrasts. In the former, the pleasure of the green meadow (125 $\chi \lambda \omega \rho$ ò $\lambda \iota \beta a \delta o \tau o ́ \pi \iota)$ contrasts with the hero's unhappy song expressing the deep sorrow caused by his exile; and his fighting against his father's knights takes place here - Velthandros leaves the meadow having prevailed over others, both in words (like Kallimachos) and physical strength, since the knights are unable to convince the prince to return home and ten of them are killed by him. Kallimachos and Velthandros show the same attitude in arguing to continue on their path, from the meadow into foreign territory. Livistros, on the other hand, actually opens with a scene of crossing, the hero passing through a sloping meadow (28

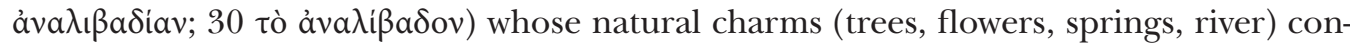
trast with the hero's grief, his sighs and tears caused by love. This meadow presents the opposite situation to the other two: rather than convincing Klitovon to do something, as Kallimachos and Velthandros do, Livistros is convinced by him instead. Furthermore, when crossing a beautiful flowery meadow (205 $\lambda \iota \beta a ́ \delta ı v ~ \pi a v \varepsilon \xi \alpha i \rho \varepsilon \tau o v ~ \mu \nu \rho ı a v \theta ı \sigma \mu \varepsilon \dot{v o v ; ~ c f . ~}$

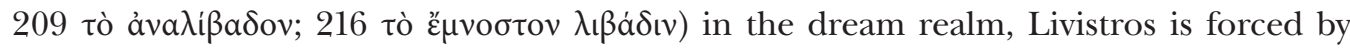
winged men to stand before Eros as his vassal. ${ }^{23}$ Both these charming spots in Livistros display the opposing pairs delight and sorrow, young hero and winged men, real world and dream world, kingly rank and vassalage. ${ }^{24}$

the inherent liminality of the marvelous space," see Cupane (2014: pp. 190-191). On the opening dream sequence in Livistros from a structural and a spatial point of view, see Agapitos (1999: pp. 111-147).

23 There are two other meadows in Livistros, one located in Egypt, the other on the way back to the Argyrokastron (Silver Castle) after the escape from Egypt. On the spatial features of these two meadows, see Agapitos (1991: pp. 316 and 319).

24 Turner's theory on liminal entities relates to the ambiguous nature of liminality: "The attributes of liminality or of liminal personae ('threshold people') are necessarily ambiguous [...]. Liminal entities are neither here nor there; they are betwixt and between the positions assigned and arrayed by law, custom, convention, and ceremonial" (Turner 1991: p. 95). He goes on to mention a series of binary oppositions contrasting the properties of liminality and those of the status system (pp. 106-108). Turner also speaks of submissiveness as a characteristic of liminality (p. 103). In these three late Byzantine romances, all three 
Located at the top of the mountain, whose ascent is beyond most, Kallimachos' heavenly meadow is divided at its center by a river. Rivers are also natural borders marking the limits of territories. The kingdom of Chrysorrhoe's parents is surrounded by a river that runs down from a mountain (KC 655-662). In this Byzantine romance, the river not only has a topographical function of delimiting a territory. It is also linked to the lovers' refuge, allowing the isolation of the young couple. The shining golden castle, a place of dragons and torture at first but later a place of love where Kallimachos and Chrysorrhoe engage in their first amorous experience, ${ }^{25}$ is surrounded by a river (KC 831, 876). Likewise, in the foreign king's palace, where Chrysorrhoe is taken after Dragon's Castle, the princess orders the installation of a pavilion in the middle of the garden, surrounded by a water channel (KC 1869-1870, 1877-1878), ${ }^{26}$ where Chrysorrhoe seeks seclusion and her secret nocturnal meetings with Kallimachos take place. The river in Velthandros is a remarkable example of the transition between worlds. While he wanders over foreign lands, Velthandros comes upon a flaming river (VC 236-239) and decides to follow it upstream until he finally reaches the Erotokastron; he enters Love's domain, where he meets his future bride and undergoes his initiation in love. Towards the end of the story, hero and heroine elope from Antioch and must cross a flooded river ( $V C$ 1101-1117) in order to return to Velthandros' homeland. While following the flaming river upstream leads characters away from the real world, the flooded river takes them downstream back to it. ${ }^{27}$

In Kallimachos, the exit from the known human world is also marked by the absence of people. After leaving the meadow behind, the brothers come to "a region of cliffs, where

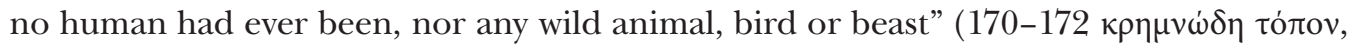

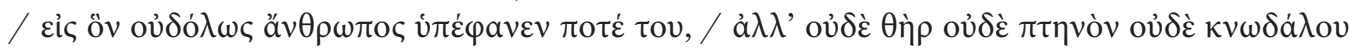

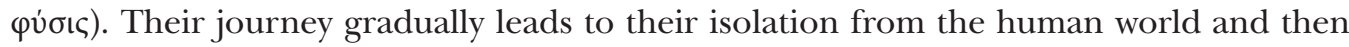
from each other: the king's three sons leave home with a tremendous force of soldiers and servants; before the mountain they detach themselves from the army and ascend alone; confronted with Dragon's Castle, it is Kallimachos alone who faces the dangerous fortress guarded by dragons. First the hero says goodbye to his father, then to his army, and finally to his brothers. He manages to enter the castle by himself, and thus comes to know all the wonders and beauties it holds inside. The number of characters along the journey is gradually reduced to one, and the transition from group to individual paral-

heroes abandon their princely status in order to be a king's subject: Livistros becomes King Eros' vassal; Velthandros offers himself as vassal to the King of Antioch; Kallimachos is hired as the gardener's helper at the foreign king's palace.

25 Cupane (1978: pp. 238-239) has already pointed out that after the slaying of its evil lord, Dragon's Castle becomes Golden Castle, a delightful paradise for the young couple. On the ambivalent image of Dragon's Castle, see also Agapitos (1991: p. 288).

26 On the erotic function of water in Kallimachos, see Agapitos (1991: pp. 293-297).

27 On the spatial organization of Velthandros and its symmetrical narrative progress, see Agapitos (1991: p. 301); Beaton (1996a: pp. 121-125; esp. 122 on the liminal role of the two rivers). Cupane (2014: p. 192) also writes that the flaming river in Velthandros "marks the boundaries between the real space and the wondrous one". 
lels the reduction of sound to silence. ${ }^{28}$ Spatial thresholds cause separation from the group, allowing passage to regions empty of sound and speech: at the foot of the mountain there are three speeches, one from each brother (KC 83-88, 90-100, 101-137); in the meadow, there is only one, by Kallimachos (KC 160-166); throughout the region of cliffs absolute silence prevails - the lack of dialogue between the three travelers matches the desolate landscape where no human or animal sounds are heard.

Moennig argues that this journey to Dragon's Castle subtly resembles a katabasis: the author of this late Byzantine romance "takes the traditional metaphor of love Paradise almost literally and integrates it into the story." ${ }^{29}$ The journey of the three brothers is one to the earthly Paradise (iter ad paradisum), one of the major subtypes of katabasis according to Moennig. The travelers engage in the ascent of an impossibly tall mountain which bears no trace of human presence, and reach the top to find themselves in a locus amoenus, the heavenly meadow. Next they see the golden city of Dragon's Castle: the oldest brother believes that in entering it, Kallimachos would be taken down "to the very gates of death," ${ }^{30}$ which in fact would make this a real, not only metaphorical, katabasis, a true descent to the underworld.

\section{The castle, the ring, and the apple}

The walls of Dragon's Castle resemble the mountain, in terms of their physical height and terrifying aspect. However, they contrast materially with the three natural spaces. While the mountain, the meadow, and the cliffs are natural spaces of stone, wood, and water, the castle is constructed of gold, pearls, and precious stones. The mountain is wild

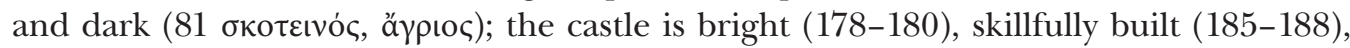

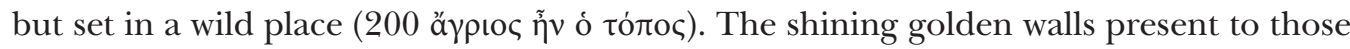
who see them from the outside a wonderfully terrifying beauty. Along the journey the three brothers have made together, the less heroic behavior of the elder two has already brought out Kallimachos' outstanding courage. Getting inside Dragon's Castle requires a new climb, which again is beyond the ability of most. The castle represents a border the two older brothers are unable to cross. They behold it only from the outside and therefore remain ignorant of the wonders held inside.

Entry into this strange and dangerous, though marvelous and charming, castle represents a transition into another stage of the hero's transformational process. Van Gennep writes of the symbolic meaning of doors in rites of passage: "the door is the boundary between the foreign and the domestic worlds in the case of an ordinary dwelling, between the profane and the sacred worlds in the case of a temple. Therefore to cross the

28 According to Turner (1991: p. 103), silence is an attribute of liminal entities.

29 Moennig (2014: p. 171).

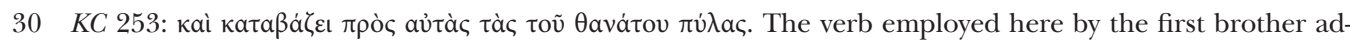

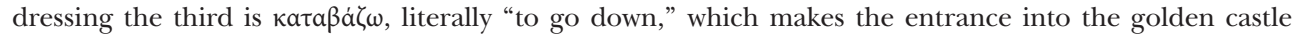
resemble a descent to the underworld. Castillo Ramírez (2000: pp. 94ff.) also conceives Kallimachos' journey from his homeland to Dragon's Castle as a symbolic journey to the world of the dead. 
threshold is to unite oneself with a new world." ${ }^{11}$ In this Byzantine romance, entry into Dragon's Castle represents Kallimachos' initiation into love, his changing from non-lover to lover. ${ }^{32}$ Yet he does not cross this threshold in the most traditional way. Evading the fearsome doorkeepers, the ever-wakeful dragons protecting the entrance of the castle, Kallimachos seeks another way in, and jumps over the walls. This transgression (passing unnoticed over the walls rather than the conventional way through the main doors) $)^{33}$ anticipates his action within: as a foreigner and uninvited guest he comes to slay the lord of the castle and to replace him. Very different is the exemplum of Livistros, who enters the Argyrokastron (Silver Castle) through the main gates, acclaimed as the winner of his combat against Verderichos, thus becoming Rhodamne's rightful husband-to-be. Immediately after scaling the walls, Kallimachos finds himself in a garden full of wonders. Just as the top of the terrifying mountain offered a charming meadow, so the walls of Dragon's Castle offer this beautiful garden. The walled garden entails a new test: the walls isolate the dragon's domain from the outside world, keep the princess inside, and stand as a defensive barrier against outsiders. The hero learns of Chrysorrhoe's existence and conquers her affection only after he has managed to breach the walls. ${ }^{34}$

Dragon's Castle is as marvelous on the inside as it is on the outside. The inner spaces Kallimachos goes through are magnificent, bright with gold, precious stones, and pearls. The whole castle (like its walls, towers, and gates) is made from a harmonious blend of these luxury materials. The castle is empty of people, ${ }^{35}$ but full of precious and luxurious furniture: the golden pool is shown to be skillfully built, lit up by well-adjusted mirrors in the place of costly marble cladding; its golden dome is decorated with a tree, also made of gold, bearing jewels in place of fruit; the golden cornice of the pool resembles a twisted vine; the rose water of the pool comes from a human head fashioned in gold; the pool's doors are made of exotic Indian and Arabian wood; the furnace is filled with Indian aloes; the table and the tableware are a splendid work of art in gold; the golden couch shines with pearls and rubies; on a second table there are all sorts of vessels beautifully carved from precious stones, such as spinel, ruby, and hyacinth stone; the dragon's chamber is entirely made of solid gold, its golden ceiling inlaid with pearls and stones, and furnished with a silver vessel, a golden stool, a cup made of emeralds, a small bed of precious stones, and a sword with a magnificent ruby hilt. ${ }^{36}$ It's a true golden city,

31 Van Gennep (1960: p. 20).

32 On the change of Kallimachos' status at Dragon's Castle, see Cupane (1978: pp. 240-241); Cupane (1986: pp. 61-62); Agapitos (2004: pp. 28-29).

33 On entrance other than through the door in primitive societies, and its meanings regarding rites of passage, see Van Gennep (1960: p. 25).

34 Barber (1992: p. 14).

35 The deserted castle is a fairy-tale motif. On this, see Bozóky (1974: pp. 349-356). On the influx of fairytale motifs in Kallimachos, see e.g. Diller (1977: pp. 25-40); García Gual (1982: pp. 20-29); Cupane (2019: pp. 40-68; esp. 50-51 and 58 on the Drakontokastron as a deserted castle).

36 For the extensive ekphrasis of the castle, from the outside to the inside, up to the dragon's death, see $K C$ 177-584. On this ekphrasis, see Hunger (1968: pp. 416-417); Agapitos (1991: pp. 263-264). The description of castles in late Byzantine romances has been widely analyzed by scholars from different perspectives. See e.g. Cupane (2015: pp. 93-118) on reconstructing the architectural style of Byzantine imperial 


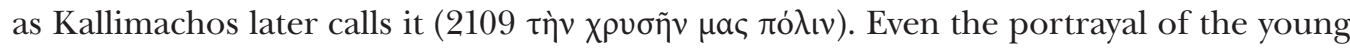
couple reflects the precious gold of the castle, since they are also sometimes referred to as "golden Chrysorrhoe" and "golden Kallimachos." ${ }^{77}$ The castle first presented as a place of golden danger and terror becomes, after the dragon's death, a place of golden beauty and love, thus creating a symbiosis with the golden beauty of the main characters.

The Drakontokastron lies in a zone of intersection, where the human world meets the supernatural. On their journey through foreign lands to Dragon's Castle, not only do the three brothers pass natural liminal spaces, they find liminal objects as well. Through them, they make contact (intentionally or not) with the worlds of magic, divinity, and death. Before the farewell scene, some distance away from Dragon's Castle, the firstborn brother offers Kallimachos a magical golden ring, telling him that he can use it to escape danger since the ring has the power to make its bearer fly (KC 261-265). However, Kallimachos doesn't use the magic power of the ring when he faces the castle's impossibly tall walls, and later in the narrative he actually loses it. The provenance of the ring is left unexplained, but like the castle it is made of gold and presented as a liminal object. According to the oldest brother, the ring makes its user grow wings. Therefore, although we don't actually see its effects at work, the ring's power to effect a symbiosis between human and animal marks the moment as liminal. By putting the ring into his mouth, the hero can grow wings and become half man, half bird, in a place where no people, animals or birds are found. He who overcomes the natural obstacles is given the opportunity to become part of the natural world, while retaining his human form. This never happens in the romance though. The non-use of the magic ring is in fact a narrator's strategy highlighting the heroism of Kallimachos, since he manages to overcome the obstacles on his way alone (entering the terrifying castle and traveling to the foreign king's palace), proving his qualities, such as courage and endurance, without resorting to magical solutions. The less magical his wanderings are, the more heroic he is. ${ }^{38}$

Regardless of its magical use, what interests us here is the liminal character of the golden ring, which holds the possibility of creating a bridge between two worlds. The human-flying animal fusion can also be seen in Livistros and Velthandros. Livistros benefits

palaces based on literary fictional elements; and Cupane (2017: pp. 101-109) on natural landscape and hand-made products of human artistry both in real buildings and in Palaiologan romances. See also Fonseca (2019: pp. 83-100) on the Homeric model for the castles in Kallimachos and Velthandros, and its blending of artificial and natural features.

37 KC 518, 1511, 2011, 2293, 2338 (golden Chrysorrhoe); and 1275, 1785, 1786, 2379 (golden Kallimachos). The name Chrysorrhoe is a compound involving gold ( $\chi \rho v \sigma o ́ \varsigma)$.

38 Magic opposes heroism, as shown by Cooper in her chapter "Magic that doesn't work" (Cooper 2008: pp. 137-172). Discussing medieval romance and the marvelous, Cooper argues that refusing or resisting the use of supernatural powers establishes the highest form of heroism: "The magic is not important in itself, but for what it reveals: human qualities at their highest can be appreciated to the full only when they are measured against the supernatural, not when they operate in conjunction with it. What we are invited to marvel at is not the magic, but at courage and endurance unaided by magic. Wonder and admiration are transferred from the supernatural to the human" (p. 143). Kallimachos' magic ring has conventionally been seen as a purposeless stock motif, mentioned and soon forgotten, playing no function whatsoever in the narrative. See García Gual (1982: p. 24); Cupane (1995: p. 74, n. 14, and p. 152, n. 104); Castillo Ramírez (2000: pp. 82 and 114). On the importance and the apparent uselessness of magical objects in Kallimachos, see Fonseca (forthcoming). 
from a supernatural aid similar to that which Kallimachos is prevented from using: he and his friend Klitovon travel to Egypt riding on flying horses over the sea. ${ }^{39}$ This human experience of engaging in the world of winged beasts is reversed in Velthandros, where birds are endowed with human feelings. Immediately after the drowning scene, where the maid Fedrokaza and three squires lose their lives, Chrysantza is saved from her quasideath thanks to a turtledove that brings her water on its wings (VC 1184-1185). The two lifesaving turtledoves near the flooded river are portrayed as if they were human, bewailing the misfortune that has befallen hero and heroine (VC 1135-1136, 1141-1143). ${ }^{40}$ To sum up, although its magical powers are not actually put to use, Kallimachos' golden ring nonetheless alludes to the symbiotic intersection of human and animal, which is a typical literary motif in late Byzantine romance.

Dragon's Castle is first presented as a terrifying and dangerous fortress, the dwelling of preternatural creatures, thus convincing Kallimachos' two older brothers to return to their homeland. However, after the hero slays the dragon and saves the princess, he becomes the castle's new master, and a change happens: Kallimachos and Chryssorrhoe integrate into the strange foreign world, making the castle their permanent home. Dragon's Castle remains dangerous to the outside world (the foreign king's retinue that comes later are as frightened as Kallimachos' brothers had been), but it is no longer so to the young couple. For hero and heroine, Dragon's Castle becomes a place of safety, a familiar environment. Danger only affects them again when they cross the gates' threshold to exit. Kallimachos' death and Chrysorrhoe's abduction result from the witch's plan to deceive them to go outside. Indoors, they were unreachable and protected. While Kallimachos had a chance to use the magic of the ring in his favor, he now falls victim to magic: he is killed by the evil ruse of a witch ${ }^{41}$ who offers him an enchanted golden apple with a double power over life and death, ${ }^{42}$ on which she has written a spell:

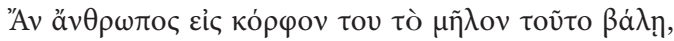

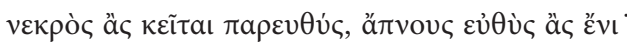

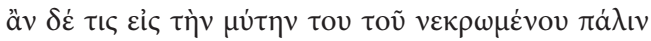

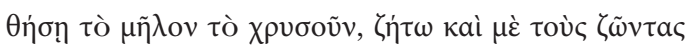

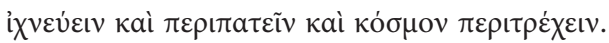

(KC 1210-1214)

39 For a detailed discussion on Livistros' magic horses, see Cupane (2009: pp. 61-79).

40 Fonseca (2019: pp. 94-95).

41 For the portrayal of witches in the Palaiologan romances as marginalized women with the power to control nature, see Goldwyn (2015: pp. 66-84); Goldwyn (2018: pp. 147-155). More recently, Stewart (2019: pp. 274-275) analyzed the ecophobia in the Palaiologan romances, relating witches to the negative picture of feminine nature and the fear of landscapes dangerously outside of mankind's control.

42 Castillo Ramírez (2000: p. 94) explains that the color of gold was thought to have its origins in the sun itself (gold being the sun turned into an object), and therefore it is related to all sort of wonders and prodigies, and notably to ancient funeral rites. Castillo Ramírez adds that the golden color of Kallimachos' apple is connected to the world of the dead, and that is why the apple holds the power to take a life away and to give it back (p. 111). 
"If anyone puts this apple into his bosom he will straightway fall dead; his breath will fail immediately. But if this golden apple is held to the nose of the dead person, he will come to life, go, walk, and traverse the world with the living."

Back in the real world of their father's kingdom, Kallimachos' brothers learn of his death through a dream. The goddess Tyche visits the two princes as the hero's personal Fortune, urging them to go to their youngest brother's aid (KC 1331-1341). Cupane argues that this is not an allegorical dream, but rather a supernatural epiphany serving the narrative function of unblocking a deadlocked situation. ${ }^{43}$ The distressed deity rushes from her divine realm, ${ }^{44}$ where she turns the wheel of destiny in an uninterrupted cycle of joys and sorrows, descends to the realm of men and appears to them as an oneiric vision. It is more than a dream, since she appears before both brothers. This visit from above takes place in a liminal zone. The frontiers between divine and human, dream and reality fade out, creating a middle zone where all realms intersect, in order that the hero be revived. So, after much effort, the two brothers reach Dragon's Castle again and find Kallimachos lying dead on a small island nearby with the golden apple on his corpse; they read its engraved spell, and use it to revive him. Kallimachos is thus a hero who returns from the dead and the underworld, as certain heroes from the mythological tradition had. His death, magically induced, is only temporary, until the double power of the apple (the second half of the spell) can be activated by his brothers. The apple is a deadly weapon that brings immediate death, but also allows the way back to life. It is a way to enter and exit the underworld; a channel connecting the two worlds of the living and the dead, allowing passage in both directions. Nevertheless, the way back to life does not depend on the one who went down to the underworld, but on the actions of others among the living. This means that the goddess Tyche must descend from above in order that Kallimachos can ascend from below. The magic apple in Kallimachos plays the same role as the witch's ring in Livistros' romance: he, too, has his life suspended right after putting an enchanted ring on his finger ( $L R$ 2667-2682), and he's revived the moment the ring is removed ( $L R$ 2690-2693). Both magical objects are created by witches on behalf of foreign kings, and both serve the purpose of making the hero fall dead in order that the heroine can be abducted. ${ }^{45}$

\section{Conclusion}

Witch and goddess, dragons and demons, human and animal, dream and reality are all connected to the supernatural Drakontokastron. ${ }^{46}$ It is a place of liminality, where other

43 Cupane (2010: p. 99).

44 For brief comments on the journey of Kallimachos' personal deified Fortune, see Agapitos (1991: pp. 288-289); Van Steen (1998: pp. 209-210); Nervo (2010: p. 266).

45 On the witch episode both in Livistros and Kallimachos, see Cupane (2009: pp. 68-69); Cupane (2014: p. 195).

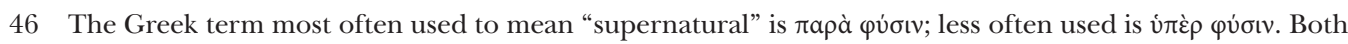


liminal entities converge. This golden castle is located in a remote, supernatural country confined by natural borders: to enter its domain, the three brothers must overcome the mountain, the meadow, the river, and the cliffs; to return to the society of men, Kallimachos likewise goes "over plains, mountains, defiles, rivers and rocky places" (1477 кá-

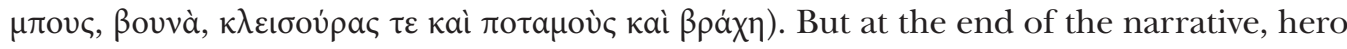
and heroine make the journey back to the place where they first met. Dragon's Castle thus plays a central role as both the driving force and goal of the action. ${ }^{47}$ The plot follows a concentric movement which takes Kallimachos from his homeland to the castle, from the castle to the foreign king's palace, and back to the castle again. This terrifying space, the dwelling place of dragons and a lover's refuge for the young couple, is set at the center of the narrative; it's a borderline within the diegetic construction, separating the two phases of the hero's storyline: the journey of adventure and the love story. On their first journey to Dragons' Castle, the three brothers face frightening places, passing from lowlands to higher ground, discovering natural and supernatural landscapes. The second journey of the two older brothers is spurred by a divine message in a dream and leads them to revive their youngest brother with magic. In its remarkable golden splendor guarded by fearful gatekeepers, Dragon's Castle inspires terror while also showing all sorts of beauties and pleasures on the inside. Kallimachos is the only one who manages to enter and to reconcile the two opposing sides of the castle's walls: the outside and the inside, the social and the private, the heroic and the erotic. Moreover, the golden objects the hero comes across (the ring, the castle's walls, and the apple) hold liminal features, ${ }^{48}$ thus in Kallimachos they bend the laws of Nature and allow the breach and/or bonding of different worlds: human and non-human, natural and supernatural, life and lifelessness.

\section{Bibliography}

Agapitos, P. A. (1991). Narrative Structure in the Byzantine Vernacular Romances: A Textual and Literary Study of Kallimachos, Belthandros and Libistros. München: Institut für Byzantinistik und Neugriechische Philologie.

Agapitos, P. A. (1999). Dreams and the Spatial Aesthetics of Narrative Presentation in Livistros and Rhodamne. Dumbarton Oaks Papers, 53, 111-147.

Agapitos, P. A. (2004). Genre, Structure, and Poetics in the Byzantine Vernacular Romances of Love. Symbolae Osloenses, 79, 7-101.

indicate something that is "beyond human nature," and most of their uses are linked to Dragon's Castle: KC 190, 218, 231, 255, 260, 278, 299, 386, 652, 958, 1553, 1558-1559, 1808, 1873. On Dragon's Castle as a supernatural and magical space located beyond the real world, see Nørgaard (1989: p. 287); Garland (1990: pp. 111-117); Cupane (2014: p. 190).

47 Cupane (1978: p. 241). On the important role played by Dragon's Castle in the narrative, see also Conca (1986: pp. 37-38).

48 Greenfield (1995: pp. 146-147) states that shining surfaces and other reflective and bright objects were commonly used in late Byzantine magic for manipulative divination. 


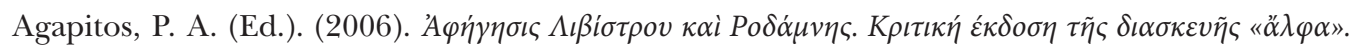

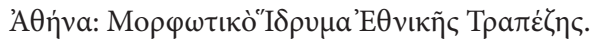

Arrignon, J.-P., \& Duneau, J.-F. (1992). Le Roman Byzantin: Permanence et Changements. In M.-F. Baslez, Ph. Hoffmann, \& M. Trédé (Eds.), Le Monde du Roman Grec (pp. 283-290). Paris: Presses de l'École Normale Supérieure.

Barber, Ch. (1992). Reading the Garden in Byzantium: Nature and Sexuality. Byzantine and Modern Greek Studies, 16, 1-19.

Beaton, R. (1996a). The Medieval Greek Romance ( $2^{\text {nd }}$ ed.). London - New York: Routledge.

Beaton, R. (1996b). The Byzantine Revival of the Ancient Novel. In G. Schmeling (Ed.), The Novel in the Ancient World (pp. 713-733). Leiden: Brill.

Betts, G. (Transl.). (1995). Three Medieval Greek Romances: Velthandros and Chrysandza, Kallimachos and Chrysorroi, Livistros and Rodamni. New York - London: Garland Publishing.

Bozóky, E. (1974). Roman médiéval et conte populaire: le château désert. Ethnologie française, 4, 349-365.

Buxton, R. (1996). Imaginary Greece: The Contexts of Mythology. Cambridge: Cambridge University Press.

Castillo Ramírez, E. (2000). El Calímaco y Crisórroe a la luz del análisis del cuento de V. Propp. Erytheia, 21, 73-118.

Chevalier, J., \& Gheerbrant, A. (1990). Dictionnaire des Symboles: Mythes, Rêves, Coutumes, Gestes, Formes, Figures, Couleurs, Nombres. Paris: Éditions Robert Laffont - Éditions Jupiter.

Conca, F. (1986). Il romanzo nell'età dei Paleologi: temi e strutture. In C. Roccardo (Ed.), Il Romanzo tra Cultura Latina e Cultura Bizantina (pp. 33-45). Palermo: Enchiridion Società Cooperativa Editorial.

Cooper, H. (2008). The English Romance in Time. Transforming Motifs from Geoffrey of Monmouth to the Death of Shakespeare. Oxford: Oxford University Press.

Cupane, C. (1978). Il motivo del castello nella narrativa tardo-byzantina. Jahrbuch der Österreichischen Byzantinistik, 27, 229-267.

Cupane, C. (1986). Topica romanesca in oriente e in occidente: «avanture» e «amour». In C. Roccardo (Ed.), Il Romanzo tra Cultura Latina e Cultura Bizantina (pp. 47-72). Palermo: Enchiridion Società Cooperativa Editorial.

Cupane, C. (1994). Lo straniero, l'estraneo, la vita da straniero nella letteratura (tardo) bizantina di fizione. In L. Mayali (Ed.), Identité et Droit de l'Autre (pp. 103-126). Berkeley: University of California at Berkeley.

Cupane, C. (Ed. \& Transl.). (1995). Romanzi cavallereschi bizantini: Callimaco e Crisorroe, Beltandro e Crisanza, Storia di Achille, Florio e Plaziaflore, Storia di Apollonio di Tiro, Favola consolatoria sulla Cattiva e la Buona Sorte. Torino: Unione Tipografico-Editrice Torinese.

Cupane, C. (2009). Itinerari magici: il viaggio del cavallo volante. In M. Cassarino (Ed.), Sulle orme di Sharazàd: Le «Mille e una notte» fra Oriente e Occidente. Atti VI Colloquio Internazionale, Ragusa, 12-14 ottobre 2006 (Medioevo Romanzo e Orientale; pp. 61-79). Soveria Mannelli: Rubbettino Editore.

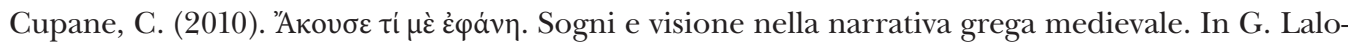
mia, \& A. Pioletti (Eds.), Temi e motivi epico-cavallereschi fra Oriente e Occidente. Atti VII Colloquio Internazionale, Ragusa, 8-10 maggio 2008 (Medioevo Romanzo e Orientale; pp. 91-114). Soveria Mannelli: Rubbettino Editore. 
Cupane, C. (2014). Other Worlds, Other Voices: Form and Function of the Marvelous in Late Byzantine Fiction. In P. Roilos (Ed.), Medieval Greek Storytelling: Fictionality and Narrative in Byzantium (pp. 183-202). Wiesbaden: Harrassowitz Verlag.

Cupane, C. (2015). Die Wirklichkeit der Fiktion. Palastbeschreibungen in der byzantinischen Literatur. In Ch. Schmid, G. Schichta, Th. Kühtreiber, \& K. Holzner-Tobisch (Eds.), Raumstrukturen und Raumausstattung auf Burgen in Mittelalter und frühen Neuzeit (pp. 93-118). Heidelberg: Universitätsverlag Winter.

Cupane, C. (2016a). In the Realm of Eros: The Late Byzantine Vernacular Romance - Original Texts. In C. Cupane, \& B. Krönung (Eds.), Fictional Storytelling in the Medieval Eastern Mediterranean and Beyond (Brill's Companions to the Byzantine World, 1; pp. 95-126). Leiden - Boston: Brill.

Cupane, C. (2016b). "Let me tell you a wonderful tale": Audience and Reception of the Vernacular Romances. In C. Cupane, \& B. Krönung (Eds.), Fictional Storytelling in the Medieval Eastern Mediterranean and Beyond (Brill's Companions to the Byzantine World, 1; pp. 479-494). Leiden - Boston: Brill.

Cupane, C. (2017). Wilde und gezähmte Natur. Beobachtungen zur Wahrnehmung von Natur und Landschaft in der byzantinischen Literatur. In H. Baron, \& F. Daim (Eds.), A Most Pleasant Scene and an Inexhaustible Resource. Steps Towards a Byzantine Environmental History (pp. 101-109). Mainz: Verlag des Römisch-Germanischen Zentralmuseums.

Cupane, C. (2019). Intercultural Encounters in the Late Byzantine Vernacular Romance. In A. J. Goldwyn, \& I. Nilsson (Eds.), Reading the Late Byzantine Romance: A Handbook (pp. 40-68). Cambridge: Cambridge University Press.

Diller, I. (1977). Märchenmotive in Kallimachos und Chrysorrhoe. Folia Neohellenica, 2, 25-40.

Fonseca, R. C. (2017). The Hero, the Rival, and the Dragon: The Tripartite Structure of Kallimachos and Chrysorrhoe. Parekbolai, 7, 135-149.

Fonseca, R. C. (2019). Shining castles and humans of metal/floral appearance - metaphorical language in the Palaiologan romances Kallimachos and Velthandros. Studia Philologica Valentina, 21, 83-100.

Fonseca, R. C. (forthcoming). The Ring, the Gown, and the Apple: The Role of Magical Objects in the Byzantine Vernacular Romance Kallimachos and Chrysorroi. Byzantine and Modern Greek Studies, 44.2. García Gual, C. (Transl.). (1982). Calímaco y Crisórroe. Madrid: Editora Nacional.

Garland, L. (1990). 'Be Amorous, But Be Chaste...': Sexual morality in Byzantine learned and vernacular romance. Byzantine and Modern Greek Studies, 14, 62-120.

Goldwyn, A. J. (2015). Towards a Byzantine Ecocriticism: Witches and Nature Control in the Medieval Greek Romance. Byzantine and Modern Greek Studies, 39, 66-84.

Goldwyn, A. J. (2018). Byzantine Ecocriticism: Woman, Nature, and Power in the Medieval Greek Romance. Cham, Switzerland: Palgrave Macmillan.

Greenfield, R. P. H. (1995). A Contribution to the Study of Palaeologan Magic. In H. Maguire (Ed.), Byzantine Magic (pp. 117-153). Washington: Dumbarton Oaks Research Library and Collection.

Henrich, G. S. (2012). Ein neu(artig)es Argument für den Prinzen Andrónikos als Autor von Kallimachos und Chrysorrhóé. Parekbolai, 2, 77-84.

Hunger, H. (1968). Un roman byzantin et son atmosphère: Callimaque et Chrysorrhoè. Travaux et Mémoires, 3, 405-422. 
Knös, B. (1962). Qui est l'auteur du roman de Callimaque et de Chrysorrhoé? Hellenika, 17, 274-295.

Lampaki, E. (2014). Narrative as Instruction and the Role of the Narrator in Kallimachos and Chryssorroi. In E. Camatsos, T. A. Kaplanis, \& J. Pye (Eds.), "His Words Were Nourishment and His Counsel Food": A Festschrift for David W. Holton (pp. 47-63). Newcastle upon Tyne: Cambridge Scholars Publishing.

Martini, S. C. E. (1896). A proposito d'una poesia inedita di Manuel File. Rendiconti del Reale Istituto Lombardo di Scienze e Lettere, 29 (ser. 2, fasc. 8), 460-471.

Moennig, U. (2014). Literary Genres and Mixtures of Generic Features in Late Byzantine Fictional Writing. In P. Roilos (Ed.), Medieval Greek Storytelling: Fictionality and Narrative in Byzantium (pp. 163-182). Wiesbaden: Harrassowitz Verlag.

Nervo, F. R. (2010). Il motivo del viaggio e il cronòtopo del romanzo cavalleresco bizantino. In G. Lalomia, \& A. Pioletti (Eds.), Temi e motivi epico-cavallereschi fra Oriente e Occidente. Atti VII Colloquio Internazionale, Ragusa, 8-10 maggio 2008 (Medioevo Romanzo e Orientale; pp. 261-273). Soveria Mannelli: Rubbettino Editore.

Nørgaard, L. (1989). Byzantine Romance - Some Remarks on the Coherence of Motives. Classica et Mediaevalia, 40, 271-294.

Pichard, M. (Ed. \& Transl.). (1956). Le Roman de Callimaque et de Chrysorrhoé. Paris: Société d'Édition «Les Belles-Lettres».

Priki, E. (2019). Dreams and Female Initiation in Livistros and Rhodamne and Hypnerotomachia Poliphili. In A. J. Goldwyn, \& I. Nilsson (Eds.), Reading the Late Byzantine Romance: A Handbook (pp. 69-100). Cambridge: Cambridge University Press.

Stewart, K. (2019). Literary Landscapes in the Palaiologan Romances: An Ecocritical Approach. In A. J. Goldwyn, \& I. Nilsson (Eds.), Reading the Late Byzantine Romance: A Handbook (pp. 272-298). Cambridge: Cambridge University Press.

Turner, V. (1991). The Ritual Process: Structure and Anti-structure ( $7^{\text {th }}$ print.). Ithaca - New York: Cornell University Press.

Van Gennep, A. (1960). The Rites of Passage (Transl. M. B. Vizedom, \& G. L. Caffee). London: University of Chicago Press.

Van Steen, G. (1998). Destined to Be? Tyche in Chariton's Chaereas and Callirhoe and in the Byzantine Romance of Kallimachos and Chrysorrhoe. L'Antiquité Classique, 67, 203-211.

Rui Carlos Fonseca, PhD / rui@campus.ul.pt

Centre for Classical Studies

University of Lisbon, School of Arts and Humanities

Alameda da Universidade, 1600-214 Lisboa, Portugal

This work can be used in accordance with the Creative Commons BY-SA 4.0 International license terms and conditions (https://creativecommons.org/licenses/by-sa/4.0/legalcode). This does not apply to works or elements (such as image or photographs) that are used in the work under a contractual license or exception or limitation to relevant rights. 
